\title{
Spatial modeling of the ecological niche of Pinus greggii Engelm. (Pinaceae): a species conservation proposal in Mexico under climatic change scenarios
}

\author{
Aldo R Martínez-Sifuentes (1), \\ José Villanueva-Díaz ${ }^{(1)}$, \\ Ulises Manzanilla-Quiñones ${ }^{(2)}$, \\ Jorge L Becerra-López ${ }^{(3)}$, \\ José A Hernández-Herrera ${ }^{(4)}$, \\ Juan Estrada-Ávalos ${ }^{(1)}$, \\ Adín H Velázquez-Pérez ${ }^{(5)}$
}

(1) Instituto Nacional de Investigaciones Forestales, Agrícolas y Pecuarias, Centro Nacional de Investigación Disciplinaria en Relación Agua, Suelo, Planta, Atmósfera, Gómez Palacio, Durango (México); (2) Facultad de Ciencias Forestales, Universidad Autónoma de Nuevo León, Linares, Nuevo León (México); (3) Facultad de Ciencias Biológicas, Universidad Juárez del Estado de Durango, Gómez Palacio, Durango (México); (4) Universidad Autónoma Agraria Antonio Narro, Unidad Saltillo, Saltillo, Coahuila (México); (5) Facultad de Ciencias Forestales. Colegio de Postgraduados, Montecillos, Texcoco (México)

\section{@ José Villanueva-Díaz \\ (jvilladi@prodigy.net.mx)}

Received: May 04, 2020 - Accepted: Jul 08, 2020

Citation: Martínez-Sifuentes AR, VillanuevaDíaz J, Manzanilla-Quiñones U, BecerraLópez JL, Hernández-Herrera JA, EstradaÁvalos J, Velázquez-Pérez AH (2020). Spatial modeling of the ecological niche of Pinus greggii Engelm. (Pinaceae): a species conservation proposal in Mexico under climatic change scenarios. iForest 13: 426434. - doi: 10.3832/ifor3491-013 [online 2020-09-16]

Communicated by: Maurizio Marchi

Pinus greggii is a species of socio-economic importance in terms of wood production and environmental services in Mexico, though it is restricted by particular environmental conditions to the Sierra Madre Occidental. Species distribution models are geospatial tools widely used in the identification and delineation of species' distribution areas and zones susceptible to climate change. The objectives of this study were to: (i) model and quantify the environmentally suitable area for Pinus greggii in Mexico, and possible future distributions under four different scenarios of climate change; (ii) identify the most relevant environmental variables that will possibly drive changes in future distribution; and (iii) to propose adequate zones for the species' conservation in Mexico. Some 438 records of Pinus greggii from several national and international databases were obtained, and duplicates were discarded to avoid overestimations in the models. Climatic, edaphic, and topographic variables were used and 100 distribution models for current and future scenarios were generated using the Maxent software. The best model had an area under the curve (AUC) of 0.88 and 0.93 for model training and validation, respectively, a partial ROC of 1.94 , and a significant $Z$ test $(p<0.01)$. The current estimated suitable area of Pinus greggii in Mexico was 617,706.04 ha. The most relevant environmental variables for current distribution were annual mean temperature, mean temperature of coldest quarter, and slope. For the 2041-2060 models, annual mean temperature, precipitation of coldest quarter, and slope were the most important drivers. The use of climatic models allowed to predict a future decrease in suitable habitat for the species by 2041-2060, ranging from 48,403.85 (7.8\% - HadGEM2-ES RCP 8.5 model) to $134,680.17$ ha (21.8\% - CNRM-CM5 RCP 4.5). Spatial modeling of current and future ecological niche of Pinus greggii also allowed to delineate two zones for in situ conservation and restoration purpose in northeastern (Nuevo Leon) and central (Hidalgo) Mexico.

Keywords: Conservation, Climate Change, MaxEnt, Sierra Madre Oriental, Pinus greggii

\section{Introduction}

Natural forest habitats dominated by the genus Pinus exhibit wide biological diversity and provide ecological, economic, and social benefits, such as hydrological cycle regulation, water production, carbon sequestration, promotion of biodiversity, and scenic beauty (CONAFOR 2009). Many Pinus species are exploited for commercial purposes in Mexico and represent the most important source of wood, pulp, firewood, and resin, among other products (Sánchez-González 2008).

Mexico has the second largest number of Pinus species worldwide (Gernandt \& Pérez-De La Rosa 2014), i.e., 52 out of the 111 known species (almost 50\% - Perry 1991). However, the majority of Pinus species in the country are restricted to very specific habitats and/or contrasting geographic environments. For example, Pinus caribaea var. hondurensis grows at sea level, while Pinus hartwegii is found up to $4000 \mathrm{~m}$ a.s.l., where it constitutes the upper timberline
(Gernandt \& Pérez-De La Rosa 2014). The interaction with other species, including competition, contributes to determining the ecological distribution of $P$. greggii, as well as the climatic and edaphic conditions characterizing their growing sites (CruzCárdenas et al. 2016).

Scientific evidence from Mexico indicates that the genus Pinus was always exposed to climatic changes throughout its evolutionary history. However, these changes have recently become faster due to anthropogenic activities, which caused an increase in the rate of change (Sáenz-Romero et al. 2017). Future projections foresee an increase of $2{ }^{\circ} \mathrm{C}$ in mean annual temperature by 2050 , which will threaten global biodiversity (IPCC 2019). According to climate models, three different scenarios are anticipated for Pinus spp. populations in Mexico: (i) tolerate the climatic alterations through major adaptations; (ii) become locally or regionally extinct; (iii) undergo changes in their current distribution (Davis 
\& Shaw 2001, Sáenz-Romero et al. 2015, Cruz-Cárdenas et al. 2016).

Pinus greggii Engelm. has a natural range restricted by the environmental conditions of the Sierra Madre Oriental. This species is socio-economically important in terms of firewood, fence posts, soil restoration, and the resin used to produce turpentine (Muñoz et al. 2012). In Mexico, P. greggii has been evaluated for reforestation with the aim of soil conservation and carbon sequestration (Pacheco et al. 2007). In particular, plantations of this species showed to grow well in semi-arid conditions on degraded soils (López-Peralta \& Sánchez-Cabrera 1996). Under favorable conditions, $P$. greggii showed high growth rates (Salazar et al. 1999), thus plantations of this species have also been established in other countries such as Argentina, Venezuela, South Africa, and Zimbabwe (Dvorak \& Donahue 1992).

Knowledge of the ecological niche of $P$. greggii may allow environmental managers to distinguish different environmental pat terns that contribute to establishment and distribution of the species, thereby obtaining useful information for conservation ac tivities and management of genetic resources (Hernández-Ruíz et al. 2016). Several tools are already available to this purpose (Elith et al. 2006, Booth et al. 2014), such as cartographic representations displaying the capacity of a species to occupy a particular geographic area according to a set of variables, in conjunction with continuous or categorical characteristics of the region's climatology, pedology, and topography (Guisan \& Zimmermann 2000).

MaxEnt is a spatial distribution algorithm widely used for assessing species' habitat suitability at a geographic scale (Kumar \& Stohlgren 2009) and is considered a useful tool to predict the effect of climate change on future species distribution (Peterson 2011, García-Aranda et al. 2018, ManzanillaQuiñones et al. 2019). Global circulation models are used to simulate future climate scenarios (Fernández-Eguiarte et al. 2015). Combining the current spatial distribution (ecological niche) and global circulation scenarios allows to generate a probabilistic map of future habitat suitability for a species, thus providing relevant information for its conservation and restoration programs (Sáenz-Romero et al. 2015). Indeed, MaxEnt has been successfully used to predict current and future spatial distributions of Pinaceae in Mexico (Phillips et al. 2006, Cruz-Cárdenas et al. 2016, García-Aranda et al. 2018, Manzanilla-Quiñones et al. 2019).

The negative effects of climate change (in particular drought) are expected to affect most species of the Pinaceae family in Mexico. In this context, species growing in arid or semi-arid regions, such as $P$. greggi, are likely to better face up the above effects and most areas of their current distribution to be preserved over time (niche conservatism theory - Soberón \& Miller 2009, Peterson 2011).

In this study, we analyzed geographic and environmental (climatic, topographic, and edaphic) records of $P$. greggii aiming to identify and delimit the most relevant environmental variables in current and future distributions, as well as to propose conservation areas within the current natural range of the species in Mexico. The specific goals were to: (i) estimate, identify and delimit the current range of $P$. greggii; (ii) identify the most relevant variables in the current and future (2041-2060) distribution; and (iii) propose conservation areas for $P$. greggii within its current natural range in Mexico.

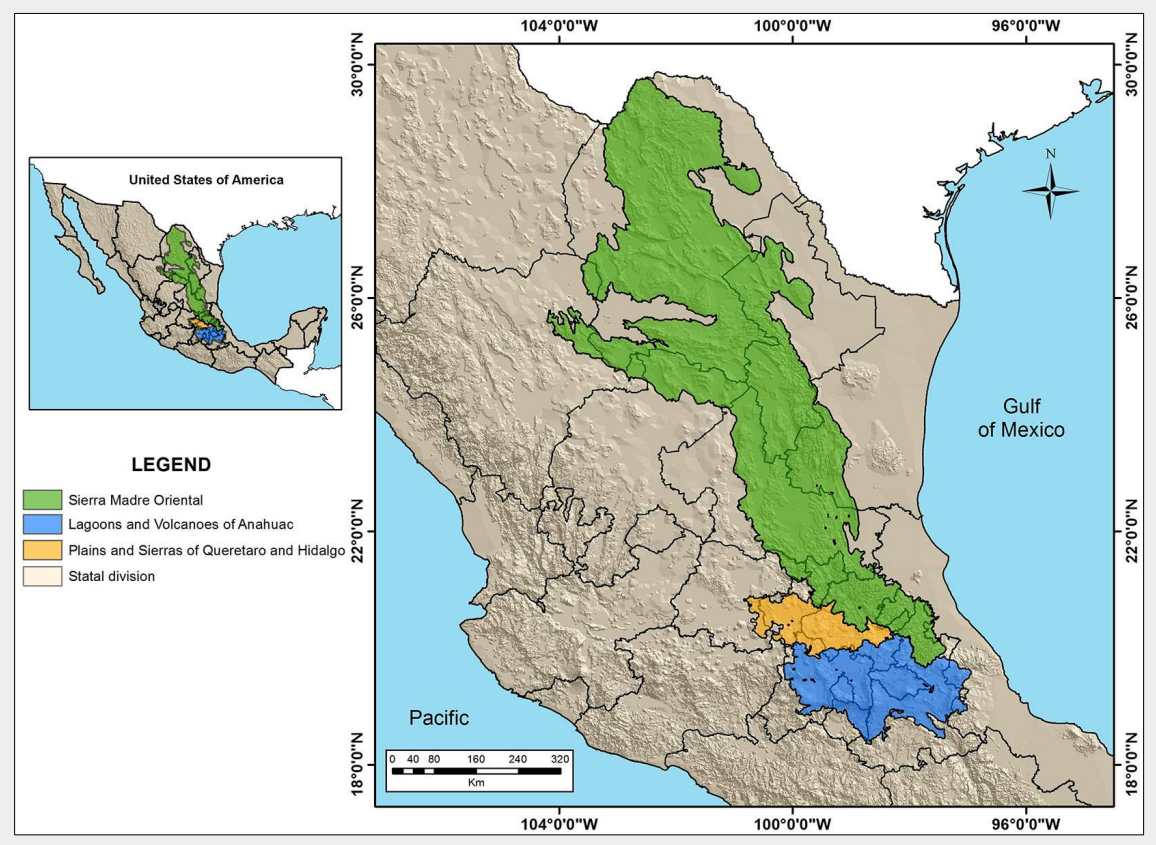

Fig. 1 - Geographical location of the study area.

\section{Methods}

\section{Study area}

The study area includes the physiographic provinces of the Sierra Madre Oriental and a portion of the Neovolcanic Transversal Belt, specifically the subprovince Plains and Sierras of Queretaro and Hidalgo, and Lagoons and Volcanoes of Anahuac (Fig. 1), between $97^{\circ}-105^{\circ} \mathrm{W}$ of longitude and $18^{\circ}$. $30^{\circ} \mathrm{N}$ of latitude (INEGI 2018). We considered the whole area including the above provinces and subprovinces as the spatial area to be modelled, based on the presence of species records therein and biological and dispersal characteristics of the species (Soberón \& Peterson 2005). The highest elevation point in the region is the Pico de Orizaba (5610 $\mathrm{m}$ a.s.I.), while the lowest is at sea level on the coast of Veracruz (INEGI 1998). The precipitation ranges from 154 to $3866 \mathrm{~mm}$, with an average of 685.09 $\mathrm{mm}$ and a mean annual temperatures range from -2 to $28{ }^{\circ} \mathrm{C}$ (Fick \& Hijmans 2017).

\section{Geographic records}

We used four different sources of spatial records for P. greggii: (i) 262 records were retrieved from the Global Biodiversity Information Facility (GBIF 2018 - https:// www.gbif.org/species/5285216); (ii) 40 records of were retrieved from the database of the National Herbarium of the Universidad Nacional Autonoma de Mexico (MEXU 2019 - http://www.ib.unam.mx/botanica/he rbario/); (iii) 63 records were retrieved from the Global Network of Biodiversity Information by CONABIO, that contain different national and international collections (REMIB 2019); and (iv) 73 records were obtained through dendrochronological expeditions made by personnel of the National Dendrochronological Laboratory of the INIFAP CENID-RASPA in 2018-2019.

In total, 438 records were collected and cleaned up via the Niche ToolBox platform of the National Commission for the Knowledge and use of Biodiversity (Osorio-Olvera et al. 2019) in order to eliminate double records and sites closer than $1 \mathrm{~km}$ each other. This step helped to avoid the autocorrelation effect and subestimation of the distribution models (Peterson \& Nakazawa 2008). Overall, 250 spatial records of $P$. greggii were considered for modeling after the cleanup process.

\section{Current and future climatic variables}

Current climatic information was obtained from the 19 bioclimatic layers (Tab. 1) of the WorldClim database ver. 2.0 (Fick \& Hijmans 2017), which contain mean climatic global information from 1970 to 2000 with a spatial resolution of $30^{\prime \prime} \times 30^{\prime \prime}(\sim 1$ $\left.\mathrm{km}^{2}\right)$. For future distribution analysis, we chose the Global Circulation Models (GCMs) CNRM-CM5 and HadGEM2-ES, which are two of the more recently used GCMs in Mexico (Manzanilla-Quiñones et al. 2019) and were generated from the 
Project of Regional Models CMIP-5 (CMIP-5 2013) of the IPCC. The bioclimatic variables of these models were downloaded with two radiative forcings of 4.5 (constant trajectories of $\mathrm{CO}_{2}$ ) and 8.5 (high trajectories of $\mathrm{CO}_{2}$ ) for 2041-2060 (Tab. 1), with a spatial resolution of $30^{\prime \prime} \times 30^{\prime \prime}\left(\sim 1 \mathrm{~km}^{2}\right)$. The list of BIOCLIM current and future layers downloaded from WorlClim ver. 2.0 is presented in Tab. 1.

\section{Topographic and edaphic variables}

Topographic information was obtained from a Digital Elevation Model (DEM) with a $30 \mathrm{~m}$ spatial resolution downloaded from the Mexican Continuous Elevation ver. 3.0 (INEGI 2018). Elevation (ELEV) and slope (SLO) variables were rescaled to a spatial resolution of $30^{\prime \prime} \times 30^{\prime \prime}\left(\sim 1 \mathrm{~km}^{2}\right)$ as ASCII layers; the SLO layer was generated from the topographic information of the DEM, and the ELEV layer was obtained from the elevation data of the DEM after the process of filling empty spaces. In both cases, the software $\operatorname{ArcMap}^{\circledast}$ ver. 10.3 was used (ESRI 2014).

Edaphic information was downloaded from the SoilGrids database (https://soilgr ids.org/\#!/?layer=ORCDRC M sl2 250m\&ve ctor $=1$ ) at a spatial resolution of $250 \mathrm{~m}$ (Batjes et al. 2017). This continuous edaphic information was developed in 2016 from the Global Soil Information Facilities (GSIF), which can be thought of as a spatial integration of a soil cartographic system at the global level (Hengl et al. 2014, 2017). SoilGrids data was generated by a model for the prediction of the physical and chemical characteristics of the soil worldwide. As for Mexico, INEGI provided series II soils profiles field data used as input for the models. Continuous variables such as coarse fragment volumetric, bulk density, absolute depth, $\mathrm{pH}$, cation exchange capacity, and soil organic carbon content were extracted and adapted to an ASCII standard format with a spatial resolution of $30^{\prime \prime} \times$ $30 "\left(\sim 1 \mathrm{~km}^{2}\right)$.

\section{Variable selection}

For variable selection, a minimum convex polygon was generated according to the presence records of $P$. greggii in the study area (Fitz-Maurice et al. 2013). Later, 10,000 points of background were added and the climatic, topographic and edaphic information of each point was extracted. Environmental variables with correlation greater than $r>0.7(p<0.01)$ were eliminated to avoid the multicollinearity effect between variables (Merow et al. 2013). The selected environmental variables were rescaled at the same spatial resolution $\left(30^{\prime \prime} \times 30^{\prime \prime}, \sim 1\right.$ $\mathrm{km}^{2}$ ) covering the whole study area, using the software ArcMap ${ }^{\circledR}$ ver. 10.3 (ESRI 2014).

\section{Current distribution modeling}

The MaxEnt ver. 3.4.1 algorithm was used for modelling current distribution to obtain the environmentally suitable area for the species (Phillips et al. 2006). This algorithm
Tab. 1 - BIOCLIM variables of current and future data downloaded from WorldClim.

\begin{tabular}{|c|c|}
\hline Variable description (Unit of measure) & Code \\
\hline Annual mean temperature $\left({ }^{\circ} \mathrm{C}\right)$ & $\mathrm{BIO1}$ \\
\hline Mean of monthly diurnal temperature range $\left({ }^{\circ} \mathrm{C}\right)$ & $\mathrm{BIO2}$ \\
\hline Isothermality & $\mathrm{BIO3}$ \\
\hline Temperature seasonality (standard deviation $\times 100,{ }^{\circ} \mathrm{C}$ ) & $\mathrm{BIO} 4$ \\
\hline Maximum temperature of warmest month $\left({ }^{\circ} \mathrm{C}\right)$ & $\mathrm{BIO5}$ \\
\hline Minimum temperature of coldest month $\left({ }^{\circ} \mathrm{C}\right)$ & $\mathrm{BIO6}$ \\
\hline Annual temperature range $\left({ }^{\circ} \mathrm{C}\right)$ & $\mathrm{BIO7}$ \\
\hline Mean temperature of wettest quarter $\left({ }^{\circ} \mathrm{C}\right)$ & $\mathrm{BIO}$ \\
\hline Mean temperature of driest quarter $\left({ }^{\circ} \mathrm{C}\right)$ & $\mathrm{BIO9}$ \\
\hline Mean temperature of warmest quarter $\left({ }^{\circ} \mathrm{C}\right)$ & $\mathrm{BIO10}$ \\
\hline Mean temperature of coldest quarter $\left({ }^{\circ} \mathrm{C}\right)$ & $\mathrm{BIO11}$ \\
\hline Annual precipitation $(\mathrm{mm})$ & $\mathrm{BIO12}$ \\
\hline Precipitation of wettest month (mm) & $\mathrm{BIO13}$ \\
\hline Precipitation of driest month (mm) & $\mathrm{BIO14}$ \\
\hline Precipitation seasonality (Coefficient of variation, \%) & BIO15 \\
\hline Precipitation of wettest quarter $(\mathrm{mm})$ & $\mathrm{BIO16}$ \\
\hline Precipitation of driest quarter $(\mathrm{mm})$ & $\mathrm{BIO} 17$ \\
\hline Precipitation of warmest quarter (mm) & $\mathrm{BIO18}$ \\
\hline Precipitation of coldest quarter (mm) & $\mathrm{BIO19}$ \\
\hline
\end{tabular}

was chosen because it is one of the most widely used methods for assessing species' potential distribution and generates accurate geographic predictions based on presence records only (Elith et al. 2006). Seventy-five percent of records were used for training the model and $25 \%$ for the validation step. The $\mathrm{BIO} 1, \mathrm{BIO} 7, \mathrm{BIO} 11, \mathrm{BIO} 15$, $\mathrm{BIO} 17, \mathrm{BIO} 19, \mathrm{ELEV}, \mathrm{SLO}$, and $\mathrm{pH}$ variables were considered (Tab. 2).

The modeling criterion comprise internal replication by cross-validation, 1000 iterations, logistic output, 100 replicates, and a convergence threshold of 0.00001 (Phillips clamping options were deactivated, to avoid overestimation in the modeling prediction (Elith et al. 2011).

Model calibration was evaluated through the standardized coefficient of the Akaike information criterion (AICC), which provides model information, such as feature type and the regularization multiplier (Warren \& Seifert 2011). The models showing the lowest AICC values were selected to generate the most accurate results. The et al. 2006). The "Extrapolate and Do" calibration was carried out using the "ENMeval" library (Muscarella et al. 2014) in the $R$ ver. 3.5.3 environment ( $R$ Core Team 2015).

\section{Modeling under future scenarios}

To model $P$. greggii distribution under climate change scenarios, the calibration parameters and the model with the best statistical performances were transferred to the MaxEnt ver. 3.4.1 software (Morrone \& Escalante 2016). The estimated area (ha) of current and future distribution of $P$. greggii was obtained from the reclassification of the continuous values of both temporal projections (current and future) in three categories of suitability or habitat probability with equal intervals (low, medium, and high) using the "reclass" tool of ArcMap ${ }^{\circledR}$ ver. 10.3 (ESRI 2014). The values of the high category were used as threshold cut to transform the continuous models to binary values (apt or non-apt) for every period servation areas were identified using the "Intersect" tool of ArcMap, based on the (Manzanilla-Quiñones et al. 2019). The con-

Tab. 2 - Environmental variables used in modeling the current distribution of $P$. greggii in Mexico.

\begin{tabular}{ll}
\hline Variable Code & Variable description (unit of measurement) \\
\hline BIO1 & Annual mean temperature $\left({ }^{\circ} \mathrm{C}\right)$ \\
\hline BIO7 & Annual temperature range $\left({ }^{\circ} \mathrm{C}\right)$ \\
\hline BIO11 & Mean temperature of coldest quarter $\left({ }^{\circ} \mathrm{C}\right)$ \\
\hline BIO15 & Precipitation seasonality $($ Coefficient of variation; \%) \\
\hline BIO17 & Precipitation of driest quarter $(\mathrm{mm})$ \\
\hline BIO19 & Precipitation of coldest quarter $(\mathrm{mm})$ \\
\hline ELEV & Elevation $(\mathrm{m})$ \\
\hline SLO & Slope $(\%)$ \\
\hline pH & Hydrogen potential $(0-14)$ \\
\hline
\end{tabular}


Tab. 3 - Performance of the models under climate change scenarios.

\begin{tabular}{lccc}
\hline Global Circulation Model & $\begin{array}{c}\text { Partial ROC } \\
\text { mean ratio }\end{array}$ & $\begin{array}{c}\text { Standard } \\
\text { error }\end{array}$ & Z test \\
\hline CNRM-CM5 (RCP 4.5) & 1.92 & 0.060 & $\mathrm{p}<0.01$ \\
\hline CNRM-CM5 (RCP 8.5) & 1.90 & 0.060 & $\mathrm{p}<0.01$ \\
\hline HadGEM2-ES (RCP 4.5) & 1.90 & 0.059 & $\mathrm{p}<0.01$ \\
\hline HadGEM2-ES (RCP 8.5) & 1.89 & 0.059 & $\mathrm{p}<0.01$ \\
\hline
\end{tabular}

simulation of current and future environmental conditions.

\section{Model validation}

The distribution models were evaluated through the statistical test of area under the curve (AUC) of the Receptor Operation Characteristics (ROC) analysis, which yields values in the range 0.0-1.0. Values from 0.7 to 0.9 indicate good model setting, while values above 0.9 indicate excellent setting (Peterson 2011). However, the utility of this analysis is strongly questioned as the algorithm uses only presence records, whereas this test requires true absences; for this reason, omission and commission errors are weighted evenly (Lobo et al. 2007). It was necessary to perform a ROC partial test in the Niche ToolBox platform from the CONABIO (Osorio-Olvera et al. 2019) to counterbalance the AUC deficiencies. ACcording to Peterson \& Nakazawa (2008), we generated 1000 replicates by bootstrapping ASCII data of every period and the presence records for the species, establishing a $5 \%$ omission error (Osorio-Olvera et al. 2019).

The ROC partial test generated values from 1 to 2, where a mean value of 1.0 indicates a random model (Lobo et al. 2007, Peterson \& Nakazawa 2008), Garza-López et al. 2016). A Z-test between the proportions of the AUC of partial ROC was per- formed to determine the statistical robustness of the models. The best model for each period was selected according to the highest value of the partial ROC, lower standard error, and statistically significant $Z(p<0.01)$. Finally, the output of the selected models for every period were used to produce a distribution map in ArcMap ver. 10.3 software (ESRI 2014).

\section{Relevant environmental variables}

The weight of each environmental variables in the current and future modelled distribution of $P$. greggi over the study area were evaluated using the Jacknife test (Phillips et al. 2006)

\section{Results}

\section{Modelling current suitable area}

The AUC values of the 100 replicates varied from 0.879 to 0.886 for training and from 0.797 to 0.930 for validation datasets, indicating good model performances. For $P$. greggii in Mexico, the best model had a partial ROC value of 1.90 (Tab. 3), an AUC of 0.881 , and 0.930 for training and validation steps, respectively. The results indicate a potential current distribution of $P$. greggii covering an area of 617,706.04 ha (Fig. 2) within the study area. The majority of the estimated area for $P$. greggii is located in the states of Nuevo Leon

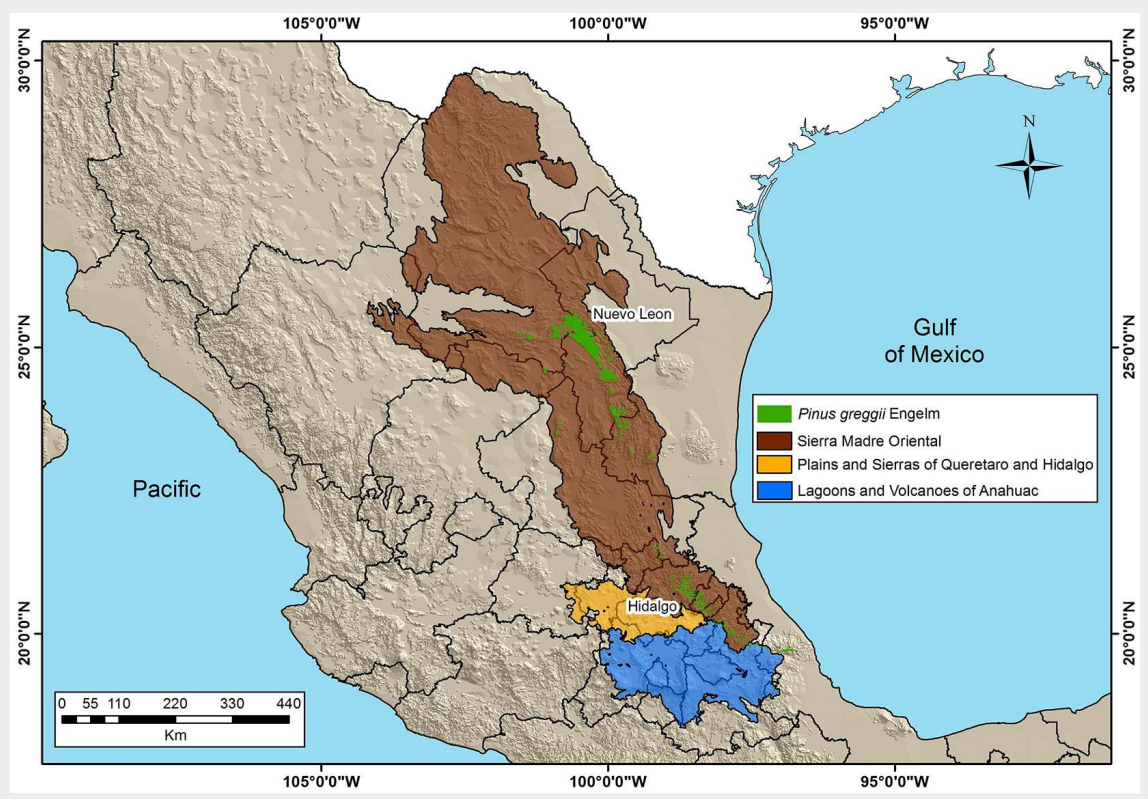

Fig. 2 - Potential current distribution model of P. greggii in the study area.
(260,028.94 ha - 42.1\%) and Hidalgo (70,762.13 ha-11.4\%).

\section{Modelling under climate change scenarios}

The AUC values obtained from the ROC test for the CNRM-CM5 RCP 4.5 model ranged from 0.901 to 0.909 for the training dataset and from 0.809 to 0.953 for the validation dataset, while the values for the RCP 8.5 projection were from 0.885 to 0.894 for training and from 0.778 to 0.942 for validation.

The results obtained for the HadGEM2-ES RCP 4.5 model showed AUC values from 0.877 to 0.888 for the training step and from 0.781 to 0.932 for the validation step, while values for the RCP 8.5 model were from 0.874 to 0.881 for training and from 0.785 to 0.936 for validation. These results allowed to classify the models of the future distribution as very good.

\section{Relevant variables in the current and future distribution}

The most relevant variables in the current distribution were $\mathrm{BIO} 1, \mathrm{BIO} 11, \mathrm{SLO}, \mathrm{BIO} 19$ and $\mathrm{BIO}_{7}$, which contributed to $81.2 \%$ of the model's variability (Fig. 3a). The relevant variables for the 2041-2060 CNRM-CM5 RCP 4.5 model were BIO1, SLO, BIO19, $\mathrm{BIO} 15$ and $\mathrm{BIO} 11$, whereas the relevant variables for the RCP 8.5 model were BIO1, $\mathrm{SLO}, \mathrm{BIO} 15, \mathrm{BIO} 19$ and $\mathrm{BIO} 11$, with contributions of $83.4 \%$ and $87.9 \%$, respectively (Fig. 3b).

The most relevant variables of the HadGEM2-ES RCP 4.5 model for 2041-2060 were $\mathrm{BIO} 1, \mathrm{SLO}, \mathrm{BIO} 11, \mathrm{BIO} 15$ and $\mathrm{BIO} 19$, with a contribution of $81.5 \%$, while for the RCP 8.5 model the variables $\mathrm{BIO} 1, \mathrm{BIO} 11$, $\mathrm{SLO}, \mathrm{BIO} 7$ and $\mathrm{BIO} 17$ had an overall contribution of $85.9 \%$ (Fig. 3C).

\section{Current and future area of $P$. greggii in \\ Mexico}

Tab. 4 presents the estimated current and future area of $P$. greggii under four climate change scenarios during 2041-2060 in the province of Sierra Madre Oriental and the subprovinces Plains, Sierras of Queretaro and Hidalgo, and Lagoons and Volcanoes of Anahuac inside the Neovolcanic Transversal Belt.

The CNRM-CM5 (RCP 4.5) model foresees an increase in mean annual temperature by $0.7{ }^{\circ} \mathrm{C}$, which will reduce the species' ecological niche by $21.8 \%$ (relative to current area). Similarly, the CNRM-CM5 (RCP 8.5) estimates a rise of $1.1{ }^{\circ} \mathrm{C}$ in mean annual temperature and an ecological niche reduction of $17.75 \%$. Both scenarios predict a shrinkage of the natural range of $P$. greggi between 2041 and 2060.

The HadGEM2-ES (RCP 4.5) model anticipated an increase of $1.5^{\circ} \mathrm{C}$ in the mean annual temperature, resulting in a reduction of the ecological niche of $11.2 \%$. The HadGEM2-ES (RCP 8.5) model indicates a reduction of the ecological niche of $7.5 \%$ relative to the current area, with an esti- 

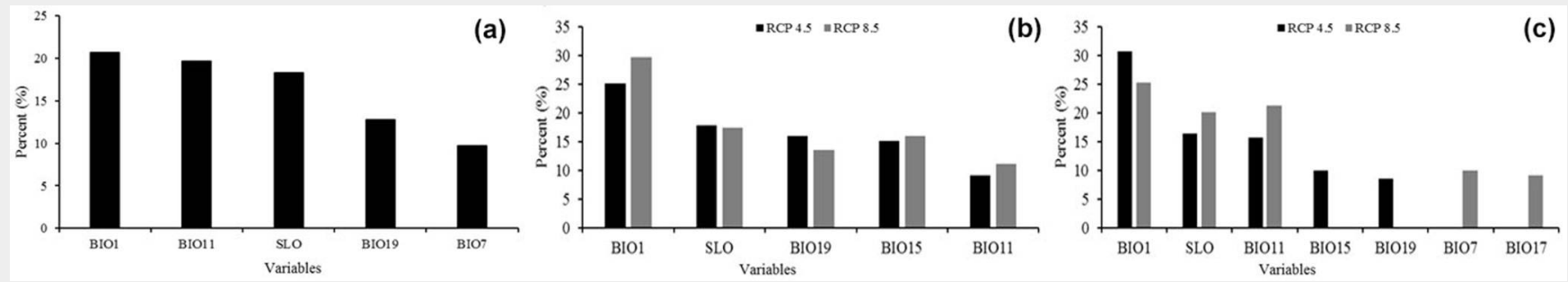

Fig. 3 - Percent contribution to model variability of the relevant environmental variables for: (a) current distribution models; (b) CNRM-CM5 RCP 4.5 and 8.5 models; (c) HadGEM2-ES RCP 4.5 and 8.5 models.

mated $2.1{ }^{\circ} \mathrm{C}$ increase of the mean annual temperature.

The four climate change scenarios considered predict from a slight reduction (HadGEM2-ES RCP 8.5: 7.8\%) to a more extensive reduction (CNRM-CM5 RCP 4.5: $21.8 \%$ ) in the ecological niche of $P$. greggii by 2041-2060. According to these models, the increase in mean annual temperature is the main responsible for the reduction of the ecological niche of $P$. greggii and the shrinkage of its future natural range.

Conservation of the ecological niche

The estimated area for the ecological niche conservation of $P$. greggii for 20412060 in Mexico, according to the CNRMCM5RCP 4.5 model was $392,923.28$ ha and $366,697.07$ ha with the RCP 8.5 model. Ar-
Tab. 4 - Potential current and future suitable area for P. greggii in Mexico. (*): Percentage of reduction with respect of the current area.

\begin{tabular}{lcc}
\hline Model & Area (ha) & Percent (\%) \\
\hline Current & $617,706.04$ & 100.0 \\
\hline CNRM-CM5 (RCP 4.5) & $483,025.87$ & $-21.8^{*}$ \\
\hline CNRM-CM5 (RCP 8.5) & $508,004.15$ & $-17.7^{*}$ \\
\hline HadGEM2-ES (RCP 4.5) & $548,374.45$ & $-11.2^{*}$ \\
\hline HadGEM2-ES (RCP 8.5) & $569,302.19$ & $-7.8^{*}$ \\
\hline
\end{tabular}

eas of 467.108.76 and 464.252.59 ha were niche conservation in 2041-2060, with a estimated according to the HadGEM2-ES $75.6 \%$ increase relative to the current estiRCP 4.5 and 8.5, respectively for 2041-2060 mated area. The conservation of $P$. greggi (Fig. 4). The interpretation of these results populations in these geographical areas is pointed to the HadGEM2-ES RCP 4.5 as the crucial for in situ restoration activities of model with the largest area of ecological the species in the next future.
Fig. 4 - Conservation areas of ecological niche of $P$. greggii in the study area under climatic change scenario models for the period 20412060. (A) CNRM-CM5 RCP 4.5; (B) CNRM-CM RCP 8.5; (C) HadGEM2ES RCP 4.5; (D) HadGEM2-ES RCP 8.5.
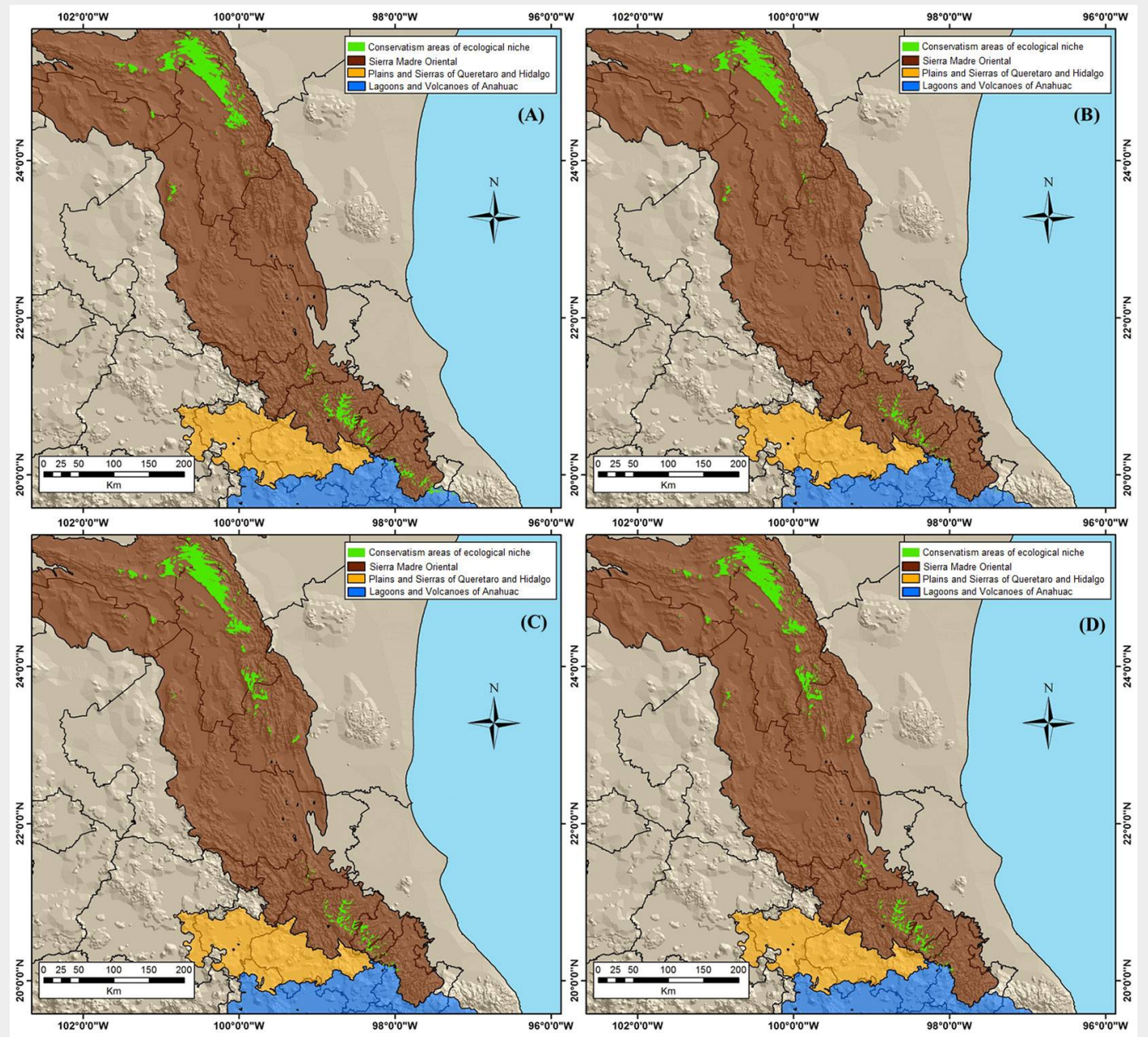


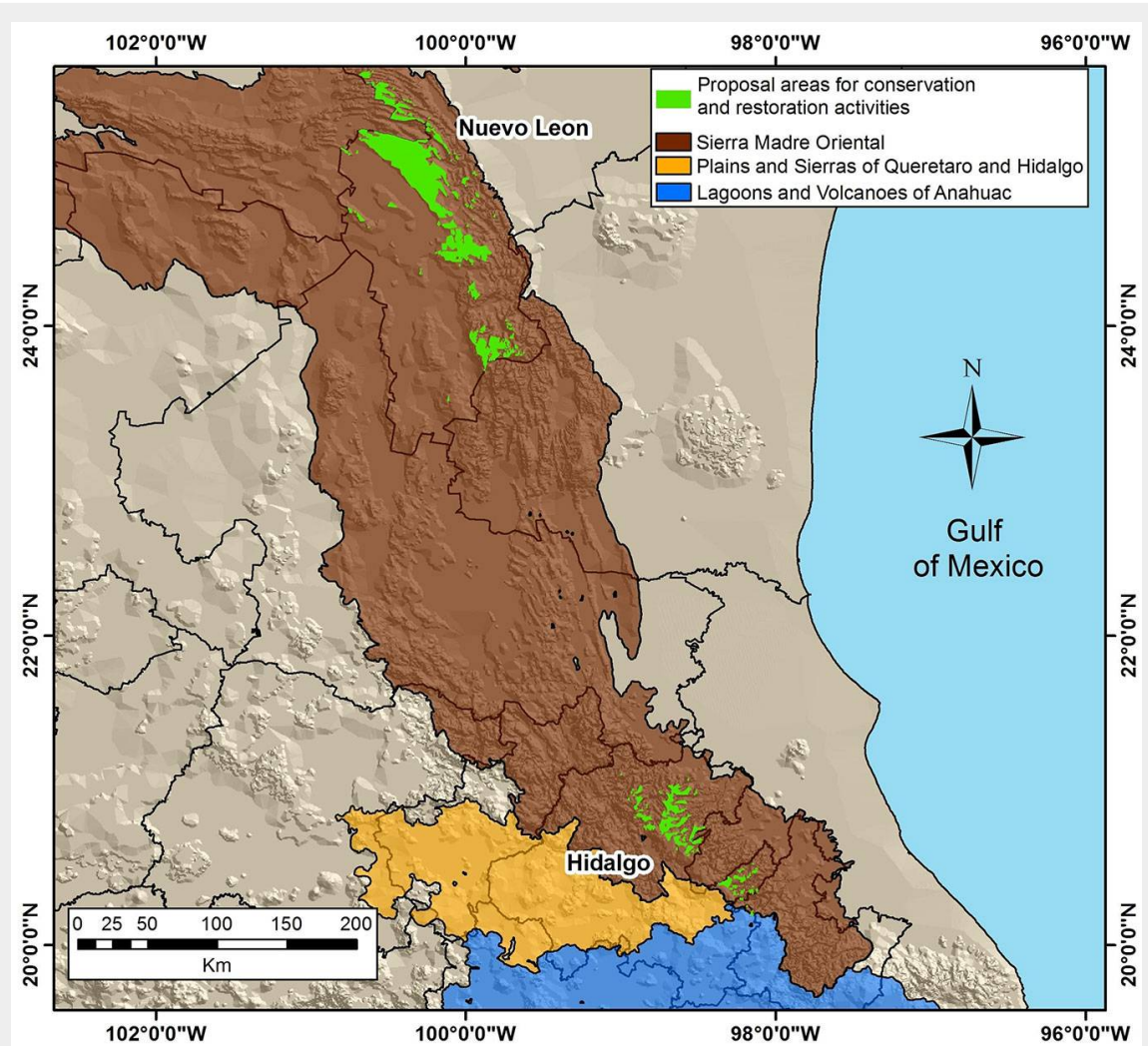

Fig. 5 - Proposal of suitable areas for in situ conservation and restoration activities of P. greggii in the study area.

The majority of the conservation areas for $P$. greggii are located in the states of Nuevo Leon (223,589.71 ha) and Hidalgo (46,341.99 ha). According to the results of the current and future model HadGEM2-ES RCP 4.5 , two suitable areas for conservation and restoration activities of the species are proposed: the first is located in the north, in the state of Nuevo Leon; the second is located in the center of the country, in the state of Hidalgo (Fig. 5).

\section{Discussion}

\section{Spatial modeling}

Current and future distribution models developed using the MaxEnt algorithm in this study showed good performances, as indicated by the AUC test for the training dataset $(0.88)$ and for the validation dataset (0.93), as well as an excellent adjustment in the partial ROC ( 1.85 to 1.94$)$ and significant values of $Z(p<0.01)$. Peterson (2011) reports that AUC values between 0.7 and 0.9 indicate a good performance of the model, and values close to 2.0 of partial $\mathrm{ROC}$ are adequate with no random effects (Peterson \& Nakazawa 2008, Garza-López et al. 2016).

The present results are based on 250 spatial records of $P$. greggii distributed over the study area. Stockwell \& Peterson (2002) suggested a minimum of 50 records to develop the species distribution analysis. Aceves-Rangel et al. (2018) modelled the potential distribution of Pinus species using only 33 records of $P$. greggii with an
AUC of 0.95 , which is higher than that obtained in the present study. Such results could be due to the smaller number of records, the lack of debugging and calibration analysis, and the inclusion of records from the state of Chiapas, though $P$. greggii is endemic of the Sierra Madre Oriental and the eastern part of the Neovolcanic Transversal Belt (Ramírez-Herrera et al. 2005).

A potential current area of $617,706.04$ ha has been estimated for $P$. greggii in this study. Contrastingly, Aceves-Rangel et al. (2018) estimated a smaller potential suitable area for the same species $(550,300$ ha). Such difference is remarkable (about $67,400 \mathrm{ha}$ ) and could be attributed to the fact that the previous study did not include edaphic variables in the model, which are considered important in modelling species potential distribution (Cruz-Cárdenas et al. 2016, Manzanilla-Quiñones et al. 2019).

\section{Relevant environmental variables}

The most important variable for $P$. greggii current distribution was $\mathrm{BIO}$, i.e., the mean annual temperature. This coincides with previous studies on Pinus habitat, which showed that this variable is a driving factor for at least ten different species (Aceves-Rangel et al. 2018). Furthermore, it confirms previous findings on the crucial role of temperature in the establishment and growth of conifer species (Wang et al. 2016), which has been corroborated by the association of drought index in arid zones (Ma et al. 2014). Indeed, elevated temperatures promote an increase in evapotranspi- ration and consequently a metabolic alteration that impacts the assimilation of photosynthates (Girardin et al. 2012), leading to a reduction in tree growth (Gennaretti et al. 2014). This should be taken into account especially in northern Mexico, where significant increases in temperature are forecast by the climatic models (Medhaug et al. 2017). Studies like Martínez-Méndez et al. (2016) and Manzanilla-Quiñones et al. (2019) found that an increase in temperature may lead to a decrease in the suitable area of Abies, Quercus, and Pinus genera.

In the study by Aceves-Rangel et al. (2018), the variable BIO11 (mean temperature of coldest quarter) was found to be relevant for $P$. arizonica, which is ecologically associated with $P$. greggii and can be found in similar climatic conditions (LópezPeralta \& Sánchez-Cabrera 1996). Analogously, García-Aranda et al. (2018) found that BIO11 plays an important role in the distribution of $P$. nelsonii in northwestern Mexico, which is also associated with $P$. greggii in the Sierra Madre Oriental and the Neovolcanic Transversal Belt. The mean value of the variable $\mathrm{BIO} 11$ was $4.3^{\circ} \mathrm{C}$ in the present study, which is very similar to the mean value found for $P$. nelsonii $\left(4.6^{\circ} \mathrm{C}\right)$.

García-Aranda et al. (2018) found that the SLO (slope) variable has great relevance in three Pinus species with distribution restricted to northeastern Mexico ( $P$. cembroides, $P$. culminicola, and $P$. nelsonii), accounting for $21.1 \%$ of the model variability, which is close to the contribution value of SLO found in this study for current distribution model of $P$. greggii (18.3\%). Indeed, Muñoz et al. (2012) mentioned that $P$. greggii is present on slopes up to a $5 \%$; the mean slope value found in this study is $8 \%$.

The $\mathrm{BIO} 19$ variable (precipitation of the coldest quarter) was considered an important variable for at least seven Abies species in Mexico (Martínez-Méndez et al. 2016). According to the study of AcevesRangel et al. (2018) BlO19 was relevant for P. lumholtzii at a national level with a lowest value of contribution to model variability of $8.2 \%$, in comparison to the $12.8 \%$ found for $P$. greggii. In this study, the BIO19 averaged over the current modelled distribution was $427 \mathrm{~mm}$. However, P. greggii is adapted to zones with low precipitation ranging from 293 to 747 mm (RamírezHerrera et al. 2005).

The annual oscillation of the temperature (BIO7) for the current distribution of $P$. greggii in the present study had a mean value of $25.4{ }^{\circ} \mathrm{C}$. This variable has been reported to be relevant in other similar studies as well. Hernández et al. (2018) found that $\mathrm{BIO} 7$ had an importance factor of $12 \%$ in the distribution of Cedrela odorata in Mexico, slightly less than our $15.5 \%$ in the present study for $P$. greggii. Martínez-Méndez et al. (2016) considered $\mathrm{BIO} 7$ a relevant environmental variable in the distribution of four species of Abies at the national level in Mexico. 


\section{Future scenarios}

Several studies about climate change scenarios have been carried out in Mexico for Pinaceae, most of which are focused on temperate and cold climates. These studies agree with the hypothesis of a significant reduction in the natural range of Pinaceae by 2050 (Sáenz-Romero et al. 2015, CruzCárdenas et al. 2016, Manzanilla-Quiñones et al. 2019). However, this type of study has not been widely applied to Pinus species growing in arid and semiarid regions of the country.

According to the increase in temperature predicted by the CNRM-CM5 and HadGEM2-ES models with two radiative forcings (RCP 4.5 and 8.5) for 2041-2060, the ecological niche of $P$. greggii will decrease between $7.8 \%$ and $21.8 \%$ within its current endemic zone, but with a tendency to modify their distribution as mentioned by Gavilán (2008).

In a modeling study of pinyon pines under climate change scenarios in Mexico, Pérez et al. (2019) found that P. culminicola, P. johannis, and $P$. pinceana will undergo a decrease in the current species' range, with a larger area predicted using RCP $8.5 \mathrm{com}$ pared to RCP 4.5. This situation is similar to that of $P$. greggii with respect to scenarios using both constant and increasing trajectories of $\mathrm{CO}_{2}$ concentration in the atmosphere, likely because all the above species grow in similar environmental conditions, i.e., arid and semiarid regions located at the bottom of the mountains (Perry 1991).

By modelling the future distribution of $P$. arizonica and $P$. cembroides (species ecologically similar to $P$. greggii), Romero-Sánchez et al. (2017) predicted by 2050 an increase in the suitable area of $52.29 \%$ and $45.95 \%$, respectively, compared to the current area in Sierra de Zapaliname, Coahuila. While the study of Romero-Sánchez et al. (2017) was regionalized, the anticipated increase in suitable areas in arid climates highlights favorable effects on species such as P. greggii, P. arizonica and P. cembroides. This suggests that, despite the global effect of climate change may be negative, some species could benefit of changing environmental conditions at local level.

\section{Conservation areas of niche}

Studies conducted on the conservation of ecological niche mention that, in order to preserve their niche, species may either adapt to climatic changes through time or move to colonize new geographical areas with characteristics similar to those of their original niche (Peterson 2011). According to Booth et al. (1988) the realized niche and parts of the fundamental niche could be measured through species distribution modeling, and the use of simulation models can assist understanding how the climatic change will affect species distribution in the future. Ecological niche modelling estimates a probabilistic index of environmental suitability over large areas for the species analysed, based on environ- mental variables of the sites where the species currently grow. Such index provides detailed information about the niche components, because it applies the niche theory as a multidimensional hypervolume proposed by Hutchinson (1957) which has been complemented with the geographical analysis by Soberón \& Peterson (2005), where some or most of environmental components are preserved allowing the species to persist at different temporal scales (Peterson 2011). However, these types of studies are very scarce so far for Mexican conifers. Martínez-Méndez et al. (2016) mention (without testing the hypothesis) that the ecological niche (as determined for Mexico) of the genus Abies remained stable over time. ManzanillaQuiñones et al. (2019) tested this hypothesis on Abies religiosa [Kuth] Schltdl \& Cham, finding that the ecological niche of this species has been preserved since 6000 years ago in the high and humid parts of the Neovolcanic Transversal Belt. In this study, we estimated $75.6 \%$ of the conservation niche using the model HadGEM2-ES RCP 4.5, indicating a smaller conservation niche area in comparison to ManzanillaQuiñones et al. (2019) for A. religiosa. This could be due to a reduction in the amount of moisture and an increase in temperature of the ecological niche of $P$. greggii.

According to the analysis of the interaction of relevant variables in the current and future distributions of Pinus greggi, it was possible to delimit two conservation niche zones suitable for conservation and restoration activities inside the current natural distribution in Mexico. Aguirre \& Duivenvoorden (2010) modelled the current and future distribution of 56 Pinus species in Mexico, and proposed to establish new protection areas for several species of this genus in the Sierra Madre Sur, where few areas that are under regulatory protection already exist. However, their study was focused on Pinus species growing in more temperate climates, which are different from the arid to semiarid zones where $P$. greggii can be found. Manzanilla et al. (2019) proposed two zones of conservation and seed production for P. pseudostrobus and P. montezumae. Although the latter species have different environmental requirements than $P$. greggii, the proposed zones of conservation and seed production are similar, with two overlapping zones from both studies.

According the objectives of this study, it was possible to estimate and delimit the current natural distribution of $P$. greggii in Mexico and the most relevant environmental variables were identified. Moreover, from the niche conservation analysis between the current and future distributions, it was possible to propose conservation areas which will likely maintain similar environmental conditions in the future.

\section{Conclusions}

Our results allowed to delimit the natural geographic distribution of $P$. greggii in the Sierra Madre Oriental and Neovolcanic Transversal Belt of Mexico. The prediction and mapping of the species distribution under four scenarios of climate change from 2041 to 2060 was also carried out.

The most important variable affecting current and future ecological niches of $P$. greggii in Mexico was the mean annual temperature, which is expected to increase due to climate change. A decrease in the natural range of $P$. greggii is predicted according to the four projected scenarios (two with constant and two with increased concentrations of greenhouse gas emissions). However, a slight increase of the suitable area outside its current range is expected by the modeled scenarios (RCP 4.5 to RCP 8.5), which will likely favor the species in the future. The regions most affected by climate change are expected to be the states of Hidalgo and Puebla, according to the four projected scenarios for P. greggii during the period of 2041-2060, though this do not imply local or regional extinction of the species therein.

Finally, the niche conservation analysis of P. greggii allowed to identify and delimit areas under similar environmental conditions (Nuevo Leon in the north, Hidalgo in Central Mexico) that could be used for in situ conservation, restoration, and forest propagation purposes.

\section{Acknowledgments}

This study was carried out through funds provided by CONACYT (Consejo Nacional de Ciencia y Tecnología, DF, Mexico), with the project no. 283134 "Red dendrocronológica mexicana: aplicaciones hidroclimáticas y ecológicas".

\section{Author Contributions}

ARMS designed the study, carried out the analysis, and wrote the paper; JVD provided a thorough review of the paper; UMQ participated in spatial analysis and editing of the paper; JLBL and JAHH provided a thorough review and edited the paper; JEA and AHVP participated in the study design and conceptualization.

\section{Conflict of interest}

The authors declare no conflict of interest.

\section{References}

Aceves-Rangel LD, Méndez-González J, GarcíaAranda MA, Nájera-Luna JA (2018). Potential distribution of 20 pine species in Mexico. Agrociencia 52 (7): 1043-1057. [online] URL: http:// www.colpos.mx/agrocien/Bimestral/2018/octnov/art-9.pdf

Aguirre GJ, Duivenvoorden JF (2010). Can we expect to protect threatened species in protected areas? A case study of the genus Pinus in Mexico. Revista Mexicana de Biodiversidad 81 (3): 875-882. [online] URL: http://www.scielo. org.mx/pdf/rmbiodiv/v81n3/v81n3a27.pdf

Batjes NH, Ribeiro E, Oostrum AV, Leenaars J, Hengl T, Mendes De Jesus J (2017). WoSIS: pro- 
viding standardised soil profile data for the world. Earth System Science Data 9: 1-14. - doi: 10.5194/essd-9-1-2017

Booth T, Nix $H$, Hutchinson $M$, Jovanovic $T$ (1988). Niche analysis and tree species introduction. Forest Ecology and Management 23: 47-59. - doi: 10.1016/0378-1127(88)90013-8

Booth T, Nix H, Busby JR, Hutchinson M (2014). BIOCLIM: the first species distribution modelling package, its early applications and relevance to most current MaxEnt studies. Diversity and Distributions 20 (1): 1-9. - doi: 10.1111/ ddi.12144

CONAFOR (2009). Restauración de ecosistemas forestales: guía básica para comunicadores [Forest ecosystem restoration: a basic guide for communicators]. Comisión Nacional Forestal CONAFOR-SEMARNAT. Zapopan, Jalisco, México, pp. 63. [in Spanish] [online] URL: http://www.conafor.gob.mx:8080/documentos /docs/7/579Restauracióndeecosistemasforestal es.pdf

CMIP-5 (2013). Coupled Model Intercomparison Project Phase 5 (CMIP-5). Intergovernmental Panel on Climate Change, University Press, Cambridge, UK - New York, NY, USA, pp. 1535.

Cruz-Cárdenas G, López-Mata L, Silva JT, BernalSantana N, Estrada-Godoy F, López-Sandoval JA (2016). Potential distribution model of Pinaceae species under climate change scenarios in Michoacán. Revista Chapingo Serie Ciencias Forestales y del Ambiente 22 (2): 135-148. - doi: 10.5154/r.rchscfa.2015.06.027

Davis MB, Shaw RG (2001). Range shifts and adaptive response to Quaternary climate change. Science 292: 673-679. - doi: 10.1126/sci ence.292.5517.673

Dvorak WS, Donahue SK (1992). The Central America and Mexico coniferous resources cooperative (CAMCORE). Research review 19801992. Department of Forestry, College of Forest Resources, North Carolina State University, Raleigh, NC, USA, pp. 1992-2085. [online] URL: http://www.cabdirect.org/cabdirect/abstract/19 950621941

Elith J, Graham C, Anderson R, Dudík M, Ferrier $S$, Guisan A, Hijmans R, Huettmann F, Leathwick J, Lehmann A, Li Jin L, Lohmann G, Loiselle A, Manion C, Moritz M, Nakamura Y, Nakazawa A, Overton J, Peterson T, Phillips J, Richardson K, Scachetti-Pereira R, Schapire E, Soberón J, Williams S, Wisz S, Zimmermann E (2006). Novel methods improve prediction of species distributions from occurrence data. Ecography 29: 129-151. - doi: 10.1111/j.2006.0906-7590.0459 $6 . x$

Elith J, Phillips SJ, Hastie T, Dudík M, Chee YE, Yates CJ (2011). A statistical explanation of MaxEnt for ecologist. Diversity and Distributions 17 (1): 43-57. - doi: 10.1111/j.1472-4642.2010. 00725.X

ESRI (2014). ArcGIS Desktop, release 10.4. Environmental System Research Institute - ESRI, Redlands, CA, USA.

Fernández-Eguiarte A, Zavala-Hidalgo J, RomeroCenteno R, Conde-Álvarez AC, Trejo-Vázquez RI (2015). Actualización de los escenarios de cambio climático para estudios de impacto, vulnerabilidad y adaptación en México y Centroamérica [Updating of climate change scenarios for impact, vulnerability and adaptation studies in
Mexico and Central America]. Centro de Ciencias de la Atmosfera, Universidad Nacional Autónoma de México, Instituto Nacional de Ecología y Cambio Climático, Mexico, DF. [in Spanish] [online] URL: http://atlasclimatico.u nam.mx/inecc/Atlas_2_190215_documentacion. pdf

Fick SE, Hijmans RJ (2017). Worldclim 2: new 1-km spatial resolution climate surfaces for global land areas. International Journal of Climatology 37 (12): 4302-4315. - doi: 10.1002/joc.5086

Fitz-Maurice B, Sotomayor M, Fitz-Maurice WA, Hernández H, Smith M (2013). Astrophytum coahuilense (Bonete de Obispo): distribución conocida, catálogo de metadatos geográficos [Astrophytum coahuilense (Bonete de Obispo): known distribution, geographic metadata catalogue]. Comisión Nacional para el Conocimiento y Uso de la Biodiversidad (CONABIO), México. [in Spanish] [online] URL: http://www. conabio.gob.mx/informacion/gis

García-Aranda MA, Méndez-González J, Hernández-Arizmendi JY (2018). Distribución potencial de Pinus cembroides, Pinus nelsonii y Pinus culminicola en el Noreste de México [Potential distribution of Pinus cembroides, Pinus nelsonii and Pinus culminicola in Northeast Mexico]. Ecosistemas y Recursos Agropecuarios 5 (13): 3-13. [in Spanish] - doi: 10.19136/era.a5n13.1396

Garza-López M, Ortega-Rodríguez JM, ZamudioSánchez FJ, López-Toledo JF, Domíguez-Alvarez FA, Sáenz-Romero C (2016). Calakmul como refugio de Swietenia macrophylla King ante el cambio climático [Calakmul as a refuge for Swietenia macrophylla King against climate change]. Botanical Sciences 94 (1): 43-50. [in Spanish] - doi: 10.17129/botsci.500

Gavilán RG (2008). La vegetación de alta montaña [High mountain vegetation]. In: "Avances en biogeografía" [Advances in biogeography] (Redondo M, Palacios M, López F, Santamaría T, Sánchez D eds). Universidad Complutense de Madrid, Facultad de Geografía e Historia, Madrid, Spain, pp. 165-174. [in Spanish]

GBIF (2018). Finnish biodiversity information facility. Global Biodiversity Information Facility (GBIF), Denmark, web site. - doi: 10.15468/dl. fpwlzt

Gennaretti F, Arseneault D, Nicault A, Perreault L, Begin Y (2014). Volcano-induced regime shifts in millennial tree-ring chronologies from northeastern North America. Proceedings of the National Academy of Sciences USA 111: 10077-10082. - doi: 10.1073/pnas.1324220111

Gernandt D, Pérez-De La Rosa JA (2014). Biodiversidad de Pinophyta (coníferas) en México [Pinophyta (conifers) biodiversity in Mexico]. Revista Mexicana de Biodiversidad 85: 126-133. [in Spanish] - doi: 10.7550/rmb.32195

Girardin MP, Guo XJ, Bernier PY, Raulier F, Gauthier $S$ (2012). Changes in growth of pristine boreal North American forests from 1950 to 2005 driven by landscape demographics and species traits. Biogeosciences 9: 2523-2536. - doi: 10.519 4/bg-9-2523-2012

Guisan A, Zimmermann NE (2000). Predictive habitat distribution models in ecology. Ecological Modelling 135 (5): 147-186. - doi: 10.1016/So 304-3800(00)00354-9

Hengl T, Mendes De Jesus J, MacMillan RA, Batjes NH, Heuvelink GB, Ribeiro E, Samuel-Rosa A,
Kempen B, Leenaars JG, Walsh M, Gonzalez MR (2014). SoilGrids1km - Global soil information based on automated mapping. PLoS One 9 (12): e114788. - doi: 10.1371/journal.pone.0105992

Hengl T, Mendes De Jesus J, Heuvelink GB, Ruiperez-Gonzalez $M$, Kilibarda $M$, Blagotić $A$, Shangguan $W$, Wright $M$, Gen $X$, Bauer-Marschallinger B, Guevara M, Vargas R, Kempen B (2017). SoilGrids250m: global gridded soil information based on machine learning. PLoS One 12 (2): e0169748. - doi: 10.1371/journal.pone.016 9748

Hernández J, Reynoso R, Hernández A, García X, Hernández-Máximo E, Cob JV, Sumano D (2018). Distribución histórica, actual y futura de Cedrela odorata en México [Historical, current and future distribution of Cedrela odorata in Mexico]. Acta Botanica Mexicana 124: 117-134. [in Spanish] - doi: 10.21829/abm124.2018.1305 Hernández-Ruíz J, Herrera-Cabrera BE, DelgadoAlvarado A, Salazar-Rojas VM, BustamanteGonzález A, Campos-Contreras JE, Ramírez-Juárez J (2016). Distribución potencial y características geográficas de poblaciones silvestres de Vanilla planifolia (Orchidaceae) en Oaxaca, México [Potential distribution and geographic characteristics of wild populations of Vanilla planifolia (Orchidaceae) in Oaxaca, Mexico]. Revista de Biología Tropical 64 (1): 235-246. [in Spanish] - doi: 10.15517/rbt.v64i1.17854 Hutchinson GE (1957). Concluding remarks. Cold Spring Harbor Symposia on Quantitative Biology 22: 415-427.

INEGI (1998). Modelo digital de elevación de alta resolución LIDAR, tipo terreno, escala 1: 250.000 [Digital LIDAR high-resolution elevation model, terrain type, scale 1: 250.000]. Instituto Nacional de Estadística y Geografía (INEGI), Aguascalientes, México. [online] URL: http://www.inegi.org.mx/app/geoz/elevaciones mex/

INEGI (2018). Áreas geoestadísticas estatales 1:250.000, edición 1 [State Geostatistical Areas 1:250.000, Issue 1]. Instituto Nacional de Estadística y Geografía (INEGI), Aguascalientes, México. [online] URL: http://www.conabio.gob. $\mathrm{mx}$ /informacion/gis/

IPCC (2019). Informe especial del IPCC sobre los impactos del calentamiento global de $1.5^{\circ} \mathrm{C}$ con respecto a los niveles preindustriales y las trayectorias correspondientes que deberían seguir las emisiones mundiales de gases de efecto invernadero, en el contexto del reforzamiento de la respuesta mundial a la amenaza del cambio climático, el desarrollo sostenible y los esfuerzos por erradicar la pobreza [IPCC special report on the impacts of global warming of $1.5^{\circ}$ $C$ relative to pre-industrial levels and corresponding trajectories that global greenhouse gas emissions should follow, in the context of strengthening the global response to the threat climate change, sustainable development and efforts to eradicate poverty]. OMMPNUMA, IPCC, Geneva, Switzerland, pp. 32. [online] URL: http://www.ipcc.ch/site/assets/uploa ds/sites/2/2019/09/IPCC-Special-Report-1.5-SPM _es.pdf

Kumar S, Stohlgren T (2009). Maxent modeling for predicting suitable habitat for threatened and endangered tree Canacomyrca monticola in New Caledonia. Journal of Ecology and Natural 
Environment 1 (4): 94-98. - doi: 10.5897/JENE.9 000071

Lobo JM, Jiménez-Valverde A, Real R (2007). AUC: a misleading measure of the performance of predictive distribution models. Global Ecology and Biogeography 17: 145-151. - doi: 10.1111/j. 1466-8238.2007.00358.x

López-Peralta MC, Sánchez-Cabrera I (1996). Pinus greggii Engelm. (Gregg Pine) and Pinus durangensis Mart. (Durango Pine). Trees IV: 374388. - doi: 10.1007/978-3-662-10617-4_22

Ma $M$, Ren L, Yuan F, Jiang S, Liu $\bar{Y}$, Kong $H$, Gong L (2014). A new standardized Palmer drought index for hydro-meteorological use. Hydrological Processes 28 (23): 5645-5661. doi: 10.1002/hyp.10063

Manzanilla-Quiñones U, Aguirre-Calderón OA, Jiménez-Pérez J, Treviño-Garza EJ, Yerena-Yamallel Jl (2019). Distribución actual y futura del bosque subalpino de Pinus hartwegii Lindl en el Eje Neovolcánico Transversal [Current and future distribution of the Pinus hartwegii Lindl subalpine forest in the Transverse Neovolcanic Belt]. Madera y Bosques 25 (2): e2521804. - doi: 10.21829/myb.2019.2521804

Manzanilla U, Delgado P, Hernández J, Molina A, Magaña JJ, Rocha M, Del Carmen A (2019). Similarity of ecological niche of Pinus montezumae and P. pseudostrobus (Pinaceae) in Mexico: implications for the selection of seed production and conservation areas. Acta Botánica Mexicana 126: 1-22. - doi: 10.21829/abm126.2019.1398

Martínez-Méndez N, Aguirre-Planter E, Eguiarte LE, Jaramillo-Correa JP (2016). Modelado de nicho ecológico de las especies del género Abies (Pinaceae) en México: algunas implicaciones taxonómicas y para la conservación [Ecological niche modeling of species of the genus Abies (Pinaceae) in Mexico: some taxonomic and conservation implications]. Botanical Sciences 94 (1): 5-24. [in Spanish] - doi: 10.17129/botsci.508

Medhaug I, Stolpe MB, Fischer EM, Knutti R (2017). Reconciling controversies about the "global warming hiatus". Nature 545 (7652): 4147. - doi: 10.1038/nature22315

Merow C, Smith MJ, Silander JA (2013). A practical guide to MaxEnt for modeling species' distributions: what it does, and why inputs and settings matter. Ecography 36 (10): 1058-1069. doi: 10.1111/j.1600-0587.2013.07872.x

MEXU (2019). Herbario Nacional de México [National Herbarium of Mexico]. Universidad Autónoma Nacional de México, Estado de México, México, web site. [in Spanish] [online] URL: http://www.ib.unam.mx/botanica/herbario

Muñoz HJ, Coria VM, García JJ, Velasco E, Martínez G (2012). Evaluación de una plantación de Pinus greggii Engelm. con dos espaciamientos [Evaluation of a Pinus greggii Engelm plantation. with two spacings]. Revista Mexicana de Ciencias Forestales 3 (11): 57-70. [in Spanish] - doi: 10.29298/rmcf.v3i11.517

Muscarella R, Galante PJ, Soley-Guardia M, Boria RA, Kass JM, Uriarte M, Anderson RP (2014). ENMeval: an $\mathrm{R}$ package for conducting spatially independent evaluations and estimating optimal model complexity for Maxent ecological niche models. Methods in Ecology and Evolutions 5: 1198-1205. - doi: 10.1111/2041-210X.12261 Morrone JJ, Escalante T (2016). Introducción a la biogeografía [Introduction to biogeography] ( $1^{\text {st }}$ edn). Universidad Nacional Autónoma de México, Estado de México, DF, México, pp. 316. Osorio-Olvera L, Vijay B, Narayani B, Soberón J, Falconi $M$ (2019). Ntbox: from getting biodiversity data to evaluating species distributions models in a friendly GUI environment. $R$ package version 0.2.5.4. [online] URL: http://github. com/luismurao/ntbox

Pacheco FC, Aldrete A, Fierros A, Cetina V, Vaquera $H$ (2007). Almacenamiento de carbono en la biomasa aérea de una plantación joven de Pinus greggii Engelm [Carbon storage in the above-ground biomass of a young Pinus greggii Engelm plantation]. Revista Fitotecnia Mexicana 30 (3): 251-254. [in Spanish] [online] URL: http://www.redalyc.org/articulo.oa?id=6100300 6

Pérez R, Romero ME, González A, Rosales S, Moreno S, Arriola VJ (2019). Modelado de la distribución actual y bajo cambio climático de pinos piñoneros endémicos de México [Modeling the current distribution and under climate change of endemic stone pines in Mexico]. Revista Mexicana de Ciencias Forestales 10 (56): 218-238. [in Spanish] - doi: 10.29298/rmcf.v10i5 6.613

Perry J (1991). The pines of Mexico and Central America. Oregon Timber Press, Portland, USA, pp. 231. [online] URL: http://www.cabdirect. org/cabdirect/abstract/19910653262

Peterson AT, Nakazawa Y (2008). Environmental data sets matter in ecological niche modelling: an example with Solenopsis invicta and Solenopsis richteri. Global Ecology and Biogeography 17 (1): 135-144. - doi: 10.1111/j.1466-8238.2007.003 47.x

Peterson AT (2011). Ecological niche conservatism: a time-structured review of evidence. Journal of Biogeography 38 (5): 817-827. - doi: 10.1111/j.1365-2699.2010.02456.x

Phillips SJ, Anderson RP, Schapire RE (2006). Maximum entropy modeling of species geographic distributions. Ecological Modelling 190 (3-4): 231-259. - doi: 10.1016/j.ecolmodel.2005. 03.026

R Core Team (2015). R: a language and environment for statistical computing. R Foundation for Statistical Computing, Vienna, Austria. [online] URL: http://www.R-project.org/

Ramírez-Herrera C, Vargas-Hernández J, LópezUpton J (2005). Distribución y conservación de las poblaciones naturales de Pinus greggii [Distribution and conservation of the natural populations of Pinus greggii]. Acta Botánica Mexicana 72: 1-16. [in Spanish] [online] URL: http:// abm.ojs.inecol.mx/index.php/abm/article/view/ 997/1158

REMIB (2019). Red mundial de información sobre biodiversidad [Global biodiversity information network]. Comisión Nacional para el Cono- cimiento y Uso de la Biodiversidad, Estado de México, web site. [in Spanish] [online] URL: http://www.conabio.gob.mx/remib/doctos/rem ibnodosdb.html

Romero-Sánchez ME, González-Hernández A, Pérez-Miranda R, Velasco-Bautista E, MorenoSánchez F (2017). Efecto del cambio climático a nivel local en la distribución potencial de cuatro especies forestales de la cuenca Río Bravo-San Juan, Coahuila, México [Effect of climate change at the local level on the potential distribution of four forest species in the Río BravoSan Juan basin, Coahuila, Mexico]. Agroproductividad 10 (8): 42-47. [in Spanish] [online] URL: http://revista-agroproductividad.org/index.php/ agroproductividad/article/view/1073

Sáenz-Romero C, Rehfeldt GE, Ortega-Rodríguez JM, Marín-Togo MC, Madrigal-Sánchez X (2015). Pinus leiophylla suitable habitat for 1961-1990 and future climate. Botanical Sciences 93 (4): 709-718. - doi: 10.17129/botsci.86

Sáenz-Romero C, Larter M, González-Muñoz N, Wehenkel C, Blanco-García A, Castellanos-Acuña D, Burlett R, Delzon S (2017). Mexican conifers differ in their capacity to face climate change. Journal of Plant Hydraulics 4: e003. doi: 10.20870/jph.2017.e003

Salazar G, Vargas H, Jasso M, Molina G, Ramírez H, López U (1999). Variación en el patrón de crecimiento en altura de cuatro especies de $\mathrm{Pi}$ nus en edades tempranas [Variation in height growth pattern of four Pinus species at early ages]. Madera y Bosques 5 (2): 19-34. [in Spanish] - doi: 10.21829/myb.1999.521345

Sánchez-González A (2008). Una visión actual de la diversidad y distribución de los pinos de México [A current vision of the diversity and distribution of pine trees in Mexico]. Madera y Bosques 14: 107-120. [in Spanish] - doi: 10.21829/ myb.2008.1411222

Soberón J, Peterson AT (2005). Interpretation of models of fundamental ecological niches and species distributions areas. Biodiversity Information 2: 1-10. - doi: 10.17161/bi.v2io.4

Soberón J, Miller CP (2009). Evolución de los nichos ecológicos [Evolution of ecological niches]. Miscelánea Matemática 49: 83-99. [in Spanish] [online] URL: http://www.miscelanea matematica.org/Misc49/4906.pdf

Stockwell RB, Peterson AT (2002). Effects of sample size on accuracy of species distribution models. Ecological Modelling 148: 1-13. - doi: 10.1016/S0304-3800(01)00388-X

Wang Y, Wang Z, Xia F, Su Y (2016). Local adaptation to temperature and precipitation in naturally fragmented populations of Cephalotaxus oliveri, an endangered conifer endemic to China. Scientific Reports 6: 1-18. - doi: 10.1038/ srep25031

Warren DL, Seifert SN (2011). Ecological niche modeling in Maxent: the importance of model complexity and the performance of model selection criteria. Ecological Applications 21: 335342. - doi: 10.1890/10-1171.1 